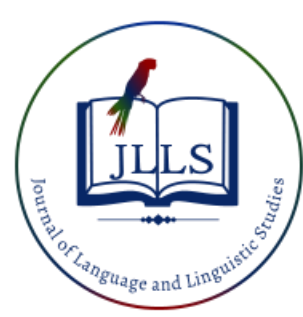

Available online at www.jlls.org

JOURNAL OF LANGUAGE AND LINGUISTIC STUDIES

ISSN: 1305-578X

Journal of Language and Linguistic Studies, 17(2), 915-923; 2021

\title{
On the use of some onomastics forms in the work Juvenilia by Mjeda
}

\author{
Shyhrete Morina a 1 iD \\ ${ }^{a}$ University of Gjakova "Fehmi Agani" Faculty of Education and Faculty of Philology, Gjakova 50000, Republic of Kosovo
}

\section{APA Citation:}

Morina, Sh. (2021). On the use of some onomastics forms in the work Juvenilia by Mjeda. Journal of Language and Linguistic Studies, 17(2), 915-923. Doi: $10.52462 /$ jlls.63

Submission Date:11/03/2021

Acceptance Date:20/05/2021

\begin{abstract}
The purpose of thie paper is to present the use of some onomastics forms in the work "Juvenilia" by Ndre Mjeda. Thus, this paper aims to reflect the anthroponyms, toponyms, hydronyms, and ethnonyms used in Mjeda's work. In this way, the findings and uses that emerge the to Mjeda, will be discussed, and the number of their uses will be shown, as well as in terms of language will be compared with today's standard Albanian. In the poems of this collection we find the names of states, cities, mountains, and rivers, we find the names of people, etc. Based on the collected material and the analysis that we will do, we will be able to answer which names of places, events and people are included in the creativity of Mjeda, in order to discover at least some of their wealth in the field of onomastics. Therefore, we can say that these onomastic features play the role of a historical document on the basis of which social developments in certain periods can be ascertained.
\end{abstract}

Keywords: anthroponyms and patronymics; ethnonyms; toponyms; oronyms and hydronyms; Mjeda.

\section{Introduction}

Linguistic research on onomastic topics is quite important since through toponyms not only the antiquity of the Albanian language is proved, but the ethnicity and the continuity of the Albanian nation also. Since they have a significant importance in the Albanian creativity work, we have addressed some linguistic features of the toponyms in Mjeda's works, mainly phonetic and morphological ones. Generally, the onomastics in Mjeda's works testifies persuasively the autochthony of the Albanian people and their language. Onomastic features in Mjeda's works take a special place, particularly toponyms and names of deities that are incorporated as historical and geographical realities in the history of the city of Shkodra. Since Mjeda was an erudite of foreign and classic languages, the history and the culture of his nation, the Balkans and more. Through his language, broad masses of readers get to know the wealth of the folk Albanian lexicon, new words and expressions created by writers, and can own them in their language use. The evidence of the today phonetic forms prove that phonetic laws expand their influence to even names of places that are too far, and only toponyms of the closest territorial circle become a part of the phonetic structure of a language.

\footnotetext{
${ }^{1}$ Corresponding author.

E-mail address: shyhrete.morina@uni-gjk.org
} 
This made it possible for a part of toponyms in Mjeda's works to be of old layers, which in some certain phonetic features have changed partially or thoroughly their phonetic form. Therefore, in Mjeda's works are study some place names (toponyms), people names (anthroponyms), and family names (patronyms). Because, of pays attention to ancient words of Albanian origin to testify the cultural Albanian authenticity, as well as the influential activity of our culture on neighboring cultures.

\subsection{Literature review}

According to Topalli (2016: 78). "in the field of onomastics, Mjeda published two articles, where his skills of an etymologist stand out: one with the title "Prend e Prendë" published in the magazine "Leka" in 1932, where he explains scientifically the origin of the days of the week in Albanian language; Thursday (Enjte) and Friday (Premte) of local origin, the others borrowings or of Latin roots. The other article, "Dromca toponomastike: "Zeta" is a response he gives to the Croatian researcher Josip Gelcić, who had published an article about Zeta and the Balshaj Dynasty”. Mjeda in his creative works, just like every other author aiming the influence and the preference by the readers, puts his thoughts and feelings, his spiritual experience, his observations on society and nature, his convictions and research, his dreams and his ideals, but, to give all this to the reader, only language tools he has in his hands, the Albanian word (Shkurtaj, 2004).

According to Shkurtaj (2002: 87) among researches and language studies Mjeda has published some scientific articles from the field of onomastics: anthroponymy, oeconyms, hydronyms and oronyms. Albanian onomastics of Albania and its regions: Shkodra, Lezha, Tivari, Preveza, Babuna, Taraboshi, Maranaji, Cukali.

According to Islamaj (2000: 226). Toponyms as a research object will clearly reflect the language of Mjeda, where we will notice the origin of the names of countries, places, cities, rivers, etc. However, a great number of toponyms in Mjeda's works will also be analyzed related to phonetics and morphological features. Having in mind that onomastics is one of the most important scientific fields that illuminate the history of nations, it presents an issue of high significance not only for poetics, but for sociology, history, and the studying of language contacts as well.

The Albanian onomastics (toponomy and anthroponomy) has been widely followed by the destiny of the Albanian nation's history. The number of cases when the Albanian toponomy, the names of mountains, cities, settlements, and rivers have faced changes is not small. Onomastics in general and toponomy in particular, make a valuable substance for any language, which can fill in a good scale the lack of written documents. It remains "the oral archive" of the history and the ancient culture of any nation. In the first researches about the antiquity and the Albanian language as one of the oldest languages in the Balkans, the researchers were oriented exactly towards the onomastics of the lands where our ancestors lived.

\subsection{Research questions}

a) With what forms go out etnonyms and a patronyms?

b) What is the main use of divind names?

c) What are the most frequent uses of toponyms in Mjeda's work?

d) What are the uses of oeconyms in the selected corpus?

e) What way are the used oronyms in Mjeda's works?

f) How of Mjeda uses the hydronyms in poems him? 


\section{Method}

For the realization for this research will be used: the method of analysis, the quantitative method of collected data and the qualitative method of interpretation of the pertinent data, as well as the comparison method in some cases. The onomastic features will be supported in the analysis and interpretation of the collected data by Mjeda's works.

\subsection{Collection of data and analysis}

In this the paper, we have extracted the data relating to the field of onomastics by from our research corpus, which for this study was Juvenilia's work by Mjeda. Toponyms, oeconyms, oronyms, and hydronyms will be supported in the analysis and interpretation of the collected data by Mjeda's works.

\section{Results and discussions}

\subsection{Toponyms and ethnonyms in Mjeda's works}

\subsubsection{Anthroponyms and patronyms}

People names or anthroponyms that are present in Mjeda's poems: Lokja, Tringa, Zoga, Mordja, Bardhyl, Agron, Teuta, Skenderbeu e.g.: Gadhnjues Bardhylin e Prediken thye (f. 145); Në gjiri të madhnueshëm, Agroni; Teuta mbretnore. In his poem "Andrra e jetës" (the dream of life), Mjeda prefers names of traditional Albanian highlands for his characters: Zoga and Tringa, both of them nonreligious and pre-Christian names, whereas for mother's figure he likes a beautiful name Loke which, being a typical highlander name but also with a suitable timbre and sounding, would remain as a favorite name in further Albanian literature. According Shkurtaj (2004: 87) Since then, the name Loke has remained as a personification of the Albanian mother in all books with topics from northern Albania.

The author brings many nouns to present the variety and specifications of individual name formation, studying old native names, divine names, historic ones, and so on. It is also interesting to point out that when Mjeda in some of his poems mentions place and people names, especially those of a historic character, he willingly approaches earlier forms as well, usually in written forms of foreign languages, especially Latin: Scodra, Lissus. Being under the influence of nonlinguistic factors such as religion, national feelings, and family traditions, the Albanian anthroponomy is quite diverse (Lutterer, 1969). In the poem "Andrra e jetës", chapter "Zoga", among others we encounter the name of a saint: Se shën Ejlli â nget, Mjedja (1990: 46).

Patronymics: There are only a few surnames in Mjeda's works, and they are found in conjunction with names, like: Meyer (Gustav), Pasha (Mahmut); Begu (Mehmet); Moreti (Pal); Topja (Karl), etc.

\subsubsection{The use of divine names in the poem "Scodra" by Mjeda}

Divine names are used a lot by Mjeda, like: Frombo, which according to a writing is explained as the divinity of Japods (Mjeda 1, f. 109). Then we see other names such as Bind the Mighty and Senton the Goddess, as water Gods are known for Illyrians, where the name Bindi is also found on a water fountain. This tells that Mjeda as an intellectual, besides Sentona, knew also about the discovery of the divine Bind altar at the water source Privilice Bihaq (Bosna), a discovery which was done and published by the archeologist Pasch by the end of the XIX century Patsch (1896: 113). In his works however, we also see mythic names, like: Ili, Galatea, Polifemi, who are adapted to the poem and mythological knowledge for them. When we are to the name Bindi, we can see it in negative use, e.g.: (Bindi damtuer qi kobe lëshote) (Bindi the harmful that calamity/death released), where we have a logical contradiction of a Bindi that was discovered in an Illyrian area, and it is known that the deities 
of seas and waters, the Greek Poseidon and the Roman Neptun with whom Bindi identifies, possess dual attributes according to mythology, as symbols of the good and the evil. For the Illyrian Bindi and dual attributes, as well as his traces in Albanian Language and mythology, Ushaku (2000: 63).

Thus, related to Bindi, Mjeda uses spontaneously the expression bind, with the meaning it has in Albanian up to now (something big; wonderment, miracle). According to Ushak (2002: 192), the research on the mythological and linguistic traces of the Illyrian Bind, the water fountain where the name Bind was carved about two thousand years ago on one of the altars dedicated to the God of waters, was discovered in the XIX century near Bihaq where the Illyrian tribe Japod lived. Comparing the Illyrian Bind to the Roman Neptun, the Greek Poseidon respectively, Ushak comes to some important results on the mythological plane. Following the chronology, he finds his traces in the VI century BC, where the mountain Pind is mentioned, as an abode of the deities, and the name of the castle Bindimiola in lower flows of the Danub river, up to the Albanian sea motifs and rituals saved in the Albanian oral heritage from the XII century onwards. On the linguistic plane, the Illyrian Bindi is not only forwarded as the name of the mountain Pind, the God of Japods' waters and the castle Bindimiola, but in the structure of the known Albanian phrases also, like: Bindi i zotit, Bindi i Botës, Bindi i Tokës (Bind of the God, Bind of the World, Bind of the Earth).

According to Ushak (2002: 194), these time and space links of trace extensions of the name Bind as a mythological name and as a linguistic trace as well, not only testify the antiquity of this word in Albanian, but they also strengthen the thesis of Illyrian-Albanian continuity in mythology and language, and at the same time the autochthony of Albanians in the coastal regions, where the name of the God of seas and waters is the greatest and the most powerful evidence from the fact that this Illyrian God of waters and seas comes out as a pandan of the most popular coastal cultures, GrecoRoman cultures.

There is also the name of Kodri, who cries out to build the castle in the royal city, which coincides with the place that Kodri takes in Greek mythology Dham (1988: 134). Other deity names are used in this poem also, such as: Poseidon, Dodonas, Elin, Zeus, Aphrodite, Rozafa. Meanwhile, Rozafa, as a sacrificial figure, together with the masonry motif as a symbol and message, indeed presents an ancient widespread phenomenon which relies on a social reality that takes root in older times of the civilizations of the Balkans and wider. Formally however, in the onomastic aspect, it does not match with the time of the foundation of Shkodra, where according to Rushaku, for the first time it appears to Barleti, as a reference in a legend for its founders. This onomastic motif, Rozafa, matches in essence and message with the base motif of sacrifice to build the Castle of Shkodra, but it departs historically and also from the religious viewpoint as an onomastic reality, thus as a name, not as a sacrifice motif from ancient times, where the phenomenon of a toponymic match and of an even more ancient origin saved in the Albanian oral tradition is not excluded.

\subsection{The presence of ethnonyms}

Ethnonyms are also present in Mjeda's works, such as: shqyptar, ingliz, grek, turk, otoman, anadollak, amerikan, shkodrin. The ethnonym shqyptar (Albanian) is used 29 times, e.g.: Detin per në tokë të Shqyptarit (Juvenilia: 56). This ethnonym has a dense use in all Mjeda's works. The ethnonym Ingliz (for English) is used 4 times, e.g.: Mbas asi zani qi e pat thirrë, e Inglizit (Juvenilia: 98). The ethnonym Otoman (for Ottoman) is used 4 times in masculine and in feminine once. The ethnonym Shkodrin (for Shkodran) is used only once. Whereas the ethnonym Turk (Turkish) is used twice, Grek (Greek) once, and Amerikan (American) is used once as well. The examination of these names presents comprehension, linguistic, and dialectal values. These shed light on many other names used 
before for provinces, cities, cultural development, religious beliefs, etc. From the etymology side, even though approximately, the native source is noticed to be dominant.

\subsection{The use of toponyms in Ndre Mjeda's works}

Toponymy is the scientific study of place names (toponyms), their origin, meanings, usage and typology. This in itself is a branch of onomastics, the study of names of all kinds. To understand the value of toponymy, recall each toponym (or geographical name) as the title of a story revealing some aspects of a cultural or natural heritage region. Toponymy, the taxonomic study of place-names, based on etymological, historical, and geographical information. A place-name is a word or word used to indicate, denote, or identify a geographic locality such as a town, river, or mountain. Toponyms, as a study object of onomastics, are an important part of the ethno-linguistic features of a province. They carry parts of the history, tell geographic realities of the past and the present of a certain area, but at the same time, they are closely connected to the inhabitants' way of living. Thus, the study of toponomy brings us very valuable data for many other sciences, which can use the saved-in-time information through nomenclature coming from different sources and eras for their specific purposes. This connects the toponomy with different disciplines, like the history of the language, ethnography, archeology, geography, etc. Based on the geographic or administrative reality, toponyms are grouped in oeconyms (names of inhabited places, where ethnonyms take part as well), hydronyms (names of waters, springs, streams, rivers, lakes) and oronyms (names of mountains, hills, lands and fields).

Toponyms were forced to submit to the pressure of Albanian phonetic laws during certain periods in history, but they also resisted the pressure from historic circumstances. This has made them to be an evidence of the development of a language in its land and in interaction with neighboring languages. our ancestors lived. According to Shkurtaj "the poems of Ndre Mjeda are a call to save and protect the territorial entirety of the Albanian nation, expressing himself clearly through toponyms that he mentions in his verses, for example: "Prej Tivarit e n'Prevezë. (From Tivar to Preveza) Mjedja (1990: 83).

No one has more beautifully and powerfully sung to the oneness and commonality of the two Albanian dialects than Ndre Mjeda, nor had such a great impact deep into the heart of the people: "Gege' e Tosk, Malci jallija/ Fund e maje nji a Shqypnija (Gheg and Tosk, Malci jallija/ bottom to top one is Albania). To the historical and geographical identification of the old name of the city which is rightly considered an Illyrian city, it is also added the form Shkodri-non in the context of this poem, like: Avullesa sinjoreve t'Shkodrinit. The poet puts this form also in the historical context, when he speaks about Labeats, Parthins, Autariats, e.g.: Prej krahinet ku i mujshëm Labeati; Përte e Parthini; Kullotë grigja e mrizon Autariati. The toponym Kraja is considered to be of later times, whereas the oronym Peshtriku is identified as a mountain in Has. Then, we have the toponym Rumia, which is considered to be of ancient times, and looking at the form of this toponym, it undoubtedly leads to an Illyrian etymology.

\subsubsection{Toponyms that name countries}

From the toponyms in Mjeda's works, we can notice that a number of them are names of countries. Out of proved toponyms, we find 6 names of countries, like: Shqypni, Turqi, Greqi, Itali, Austri dhe Francë (Albania, Turkey, Italy, Austria, and France respectively). The densest ethnonym used by Mjeda in his works is the ethnonym Shqypni, in 27 instances, like: O Shqypni e mjerë Shqypnija (f. 70 ), whereas toponyms that name countries are used 35 times in total. 


\subsubsection{The use of oeconyms and oronyms in Ndre Mjeda's works}

Oeconyms or oikonyms are also present in Mjeda's works, where we find 12 of them: Shkodra, Venediku, Stambolli, Roma, Prishtina, Peja, Lezha, Kruja, New Yorgu, Sfetigrati, Ulqini, Golemi. According to Luka (1994: 223), we encounter the name Scodra in earlier historical documents, like to the historian Polibi in the II century BC, and also to later authors. So, this is the earliest standard form documented historically, which was used by Mjeda as well.

\subsubsection{Oronyms}

Oronyms as well take a special place in his works. There are 8 oronyms: Cukal, Pashtriku, Bjeshkë t'Nemuna, Tarabosh, Shkreli, Olimp, Kelmendi, Brianza. The most used oronym is the Tarabosh mountain. According to Pavloviç (1996: 9) we have to do with an oronym being historically evidenced and included as a motif in real geographic context with mythical coloration similar to other mountains in Illyrian-Greek areas. Thus, the oronym Tarabosh consists of a composite with two parts Tara+Bosh, which according to Pavloviç (1996: 12) has been partly an etymologic study object, especially the part Tara, which comes as an oronym and hydronym in the territory of Montenegro. Based on this, we see that Mjeda as a historian, linguist and poet, might have known about the origin of this oronym Further, we see the oronym Tarabosh, used here with the poetic power of the apostrophe, epithets and apposition, interrelated with mythical motifs: O Tarabosh i mnertë, ndeja hyjnore, as a habitat of deities, which reminds us of Olimp and Pindi. So, according to Mjeda, the name Tarabosh could be linked to the name of the tribe Autarijati-bosh, the top of Autarijats (Mjeda 1, f. 156, note 3). In the context of mountains as deity residences, it is mentioned the oronym Olimp, a known mountain between Thessaly and North Macedonia, which according to mythology is the home of all deities, for example: E kjene shkuesa prej Olimpit nisun.

\subsubsection{The use of hydronyms and the number of their}

The hydronyms present in Mjeda's works are: Drini, Adriatiku, Buena, Cemi, Devolli, Bosfori, Babuna, Baltiku. According to researchers, the hydronym Buena is an old form that dates back in the $\mathrm{XV}$ century, and Mjeda uses this old form in his writings, for example: Ndër balta t'Buenës.

According to Ushak (2000: 61), here it is interwoven an old motif of water character, described in tales and legends of ancient times in the Illyro-Ballkanic area and wider, about the permanent battles between the man, the drangua and the kulshedra. The river Drin in the book "Juvenilia" is used 28 times: Val e Drinit rrotullore. This hydronym has actually a dense use in all Mjeda's works. In Mjeda's work, we also see the presence of the hydronym Adriatiku, like: Rrokulloheshin val't e Adriatikut. This hydronym has been used since ancient times, the Adriatic Sea, Adriatic Bay, or Mare Adriaticum in the oldest western maps.

\begin{tabular}{|c|c|c|c|}
\hline Toponyms & Oeconyms & Oronyms & Hydronyms \\
\hline $\begin{array}{l}\text { Albania - } 27 \\
\text { Turkey - } 1 \\
\text { Greece - } 4 \\
\text { Italy- } 2 \\
\text { France - } 1 \\
\text { Austria - } 1\end{array}$ & $\begin{array}{l}\text { Rome - } 3 \\
\text { Shkoder - } 8 \\
\text { Venice - } 1 \\
\text { Pristina - } 1 \\
\text { Peja - } 1 \\
\text { Istambul- } 3 \\
\text { New York- } 1 \\
\text { Kruje- 1 } \\
\text { Lezha - } 1 \\
\text { Sfetigrat - 3 } \\
\text { Ulcinj - 1 } \\
\text { Golem - } 2\end{array}$ & $\begin{array}{l}\text { Cukal - 1 } \\
\text { Pastriku-1 } \\
\text { Bjeshkë } \\
\text { t’Nemuna-2 } \\
\text { Tarabosh- } 8 \\
\text { Shkrel- 1 } \\
\text { Olimp- 3 } \\
\text { Kelmendi- 1 } \\
\text { Brianza- 1 }\end{array}$ & $\begin{array}{l}\text { Drini }-21 \\
\text { Adriatic }-4 \\
\text { Buna }-4 \\
\text { Devolli - } 1 \\
\text { Mississippi- } 2 \\
\text { Bosfor - } 2 \\
\text { Cemi - } 2 \\
\text { Baltiku - 1 } \\
\text { Babuna - 2 }\end{array}$ \\
\hline
\end{tabular}

Figure 1. On the uses of some onomastics forms in Ndre Mjeda's works 


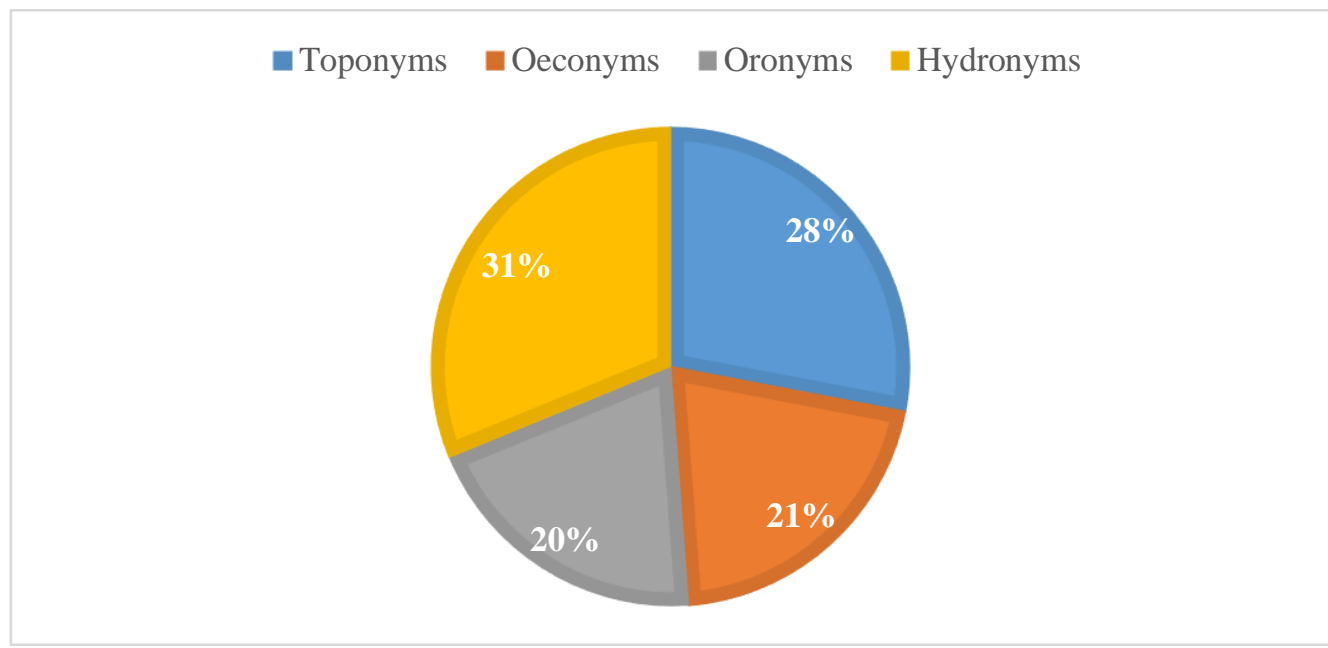

Figure 2. The use of toponyms, oeconyms, oronyms, and hydronyms in Ndre Mjeda's works

\subsubsection{Phytonyms and Zoonyms in Mjeda's works}

Phytonyms (Plant names) are borrowings from the Persian lexicon Shpuza (2008: 64) which name plants of different kinds, like:

- different kinds of flowers, such as: jasmine, viola, hyacinth, violets, roses, lilies. (jasmine, vjollca, zymyli, manushaqe, drandofille, zamakë).

- different fruit trees, such as: cherries, apples, limes etc (qershi, molla, blini, drriza etc).

- different fruitless trees, such as: çeparisa, (kiparis/ cypress) bre, bredha (spruce, pine trees), plepa (poplars), sherbel (sage). "A small bush of warm coastal regions, always green, oval shaped leaves covered with grey fluff and with a special fragrance, which is used in the folk medicine, pharmaceutical industry" etc.

Zoonyms (names of animals, birds, and insects) have also a dense use in Mjeda's works. Some words that belong to this group are borrowed from the Persian language:

- names of insects: flutur (butterfly), bletë (bee), grerëz (bumblebee), e.g.: (E pau se bleta vëlote te zgjoni).

- names of birds: bilbil (nightingale), zog (bird), shqiponjë (eagle), dallëndyshe (swallow), lejlek (stork), etc.

- names of animals: berret (livestock), e.g.: berret (cattle), mainly sheep and rams (dele, desh)" (Kush vên berret perpara n'kullosë), cows (murgjina and syka), ujk (wolf), ulkonjë (she-wolf), kali (horse), tiger, luan (lion). Mjedja (1990: 39).

\subsection{Linguistic features in Mjeda's onomastics}

We will address this onomastic authenticity starting with phonetic and morphological elements that characterize it and that can be count on as important links for linguistic studies in general. It is also interesting to mention the circumstances when Mjeda uses names of places and people in his poems, especially those with historical character; he willingly approaches the earliest forms, usually in foreign written ones, particularly in Latin, for example: Scodra, Lissus. However, in other instances he uses Albanian forms: (Shkodrë, Lesh and Lezhja respectively).

We believe that this needs to be viewed from the overall spelling tradition that Mjeda has followed while writing names of ethnic value, which, just like in the written tradition of Italian, French, German, etc, he writes with capital initials, such as: Romaku, Etolat (inhabitants of Aetolia), Iliri, 
Liburnët, Shqyptar, Gegë, Toskë, Hoten, Shkrelas, Kruetan, etc. Also, Mjeda writes with capital initials ethnicities Gegë and Toskë, and Shqype for the language /Geg'e Toskë nji zemre jemil Me ndjekë Shqype hovin tand. Further, he writes with capital initials the names: Hyji, Zot, Zojë (ShënMrija) (God, Goddess), (Perendija, i Lumi Krisht) f. 56. The poem of Mjeda "Scodra" belongs to the poetic themes where the artistic sense covered with a classic form is interlaced with his historic and mythological erudition.

The main motif for the creation of this poem was taken from the folklore tradition about building the city of Shkodra, which includes the prehistoric mythological times up to the legend of Rozafa's sacrifice. In this main motif, interwoven historical and mythological motifs are reflected in the names of the most ancient places of this region, names of deities that correspond to the Illyrian and prehistoric mythological time Ushaku (2000: 55).

The etymology of historical and mythical onomastics is a difficult job and it is not a safe one, especially in cases when in the long flow of time the motivation and the etymonof nouns with mythic tones get lost Loma (1987: 56). In the poem "Scodra" the poet addresses the Tarabosh mountain with an apostrophe and puts this undoubtedly old oronym in the mythical time and context, where the historical reality is interlaced with that of geography and covered with the mythical coloration of the deities that had their residency in mountains, analogically with Olimp, Pind and others similar in the Balkans, as well as with Drini, an old hydronym which essentially hasn't changed its name since ancient times.

Then, in later tolling, as if the idyll of a quiet life in this Illyrian area starts to get broken, and from the epithets of neighboring Elada, the envy of which gets transformed in the symbol of a kuçedra that threatens Frombo and causes harm on Poseidon's nephews, Polifem comes out on a genetic and mythic stage, who inside the tolling VI fights against the harmful and deadly Bindi ("bindit damtuer"). We also have the presence of Kodri's call, who would call to build up the residence of the kingdom. What would build up would be destroyed by a supernatural power, specifically by the fights between the Illyrian deities on Rozafa's sacrifice, as in the verse: Aferdita per flin Rozafen lypë. (Aphrodite for immolation Rozafa wants). Here also, within the mythical figurative forms and mythical-legendary events, an internal structure of the historical reality is hidden, a reality of attempts to make the Illyrian state, of disunity and fragile relationships between Illyrian tribes. Thus, we can see that these deity names are characteristic for Illyria, in particular for the Ballkans.

\section{Conclusions}

In conclusion, we emphasize that the language of Mjeda exercises a significant impact in the life of the society. After that, mythical names of deities coincide in the Illyrian context with some exceptions as mentioned above, but acceptable in the linguistic aspect. Whereas, toponyms have a mythical coloration, a historic and patriotic message, and a poetic sensation which is imposed as a beautiful truth of the poem where we learn history and mythology from, as well as linguistic features in the phonetic and morphological aspects. Regarding the study of linguistic features in Mjeda's works, we see that he paid a great attention to his writings, careful processing of his verses, rhymes, and above all he paid attention to the choice of words and proper nouns, whether they are place names (toponyms, hydronyms, old or new oeconyms), people names (anthroponyms) of early traditions, not only authentically historical, but also mythological, religious etc.

Therefore, according to our research, we see that in the works of Mjeda are present 6 toponyms that name states, which are used 36 times. The toponym that has dense use is: Albania, which is used 27 times, while other toponyms less. Then, regarding the hulumtim our, we see that in the works of Mjeda there are a total of 12 oeconyms, which are used 26 times. Whereas, the most used oeconym is: 
Shkodra, which is used 8 times. Also, the oronyms occupy a special place, since we have 8 oronyms present, and they are used 25 times in all the poems of Mjeda. The most used oronim is Tarabosh mountain, which is used 8 times. As well as, the hydronyms have a dense use in all his poems, which appear present 9 hydronyms, which are used 39 times in all the poems of Mjeda. Whereas, the most used hydronym comes out Drini, which is used 21 times, and other hydronyms are used less.

The finally, we will mention some linguistic characteristics of these onomastic features, Mjeda uses Latin names in the poem titles, such as: Scodra, Lissus. Mjeda, writes in capital letters the names: God, God, Lady, Saint Mary, God, the River Christ, Etolat, Illyria, Liburnians, Toska, Hoten, Shkrelas, Kruetan. Also, he writes some ethnonyms in capital letters: Albanian, Roman, Anatolian, Ottoman, and some names of Mjeda are different from standard Albanian, as: Buena for Buna; Shqypni for Albania; Ottoman for Osman.

\section{References}

Ismajli, R. (1979). Some issues of medieval onomastics. Pristina: Academy of Sciences and Art of Kosovo.

Ibrahimi, M. (2016). Ethnolinguistic views in the novel "Rrengu" by Murat Isaku. Tetovo: South East European University.

Ibrahimi, M. (2016). Ethnolinguistic features in the dictionary of the dialect of the Arbëneshs of Zadar by Kruno Krstic. Pristina: Albanological Institute of Pristina.

Ibrahimi, M. (2009). Dictionary of Albanian jargons and euphemisms. Skopje: Interlingua.

Ibrahimi, M. (2015). Lexical-phraseological the treatment of Albanian. Skopje: Interlingua.

Luka, D. (2012). Linguistic studies XIV (The magic of word in the work "Lahuta e Malcis" by Gjergj Fishta. Shkodra: Institute of Albanian Studies "Gjergj Fishta".

Milivoj, P. (1996). Traces of the oldest ornaments in Illyricum. Albanological research 3/1966. Pristina: Faculty of Philosophy of Pristina.

Mjedja, N. (1990). Juvenilia. Pristina: Rilindja.

Shkurtaj, Gj. (2001). Onomastics and ethnolinguistics. Tirana: University of Tirana.

Shkurtaj, Gj. (2004). Ethnography of to spoken Albanian. Tirana: The Publishing House of the University Book.

Shpuza, J. (2008). Onomastic reflection. Idromeno. Shkodra: Scientific Bulletin.

Tirta, M. (2004). Mythology among Albanians. Tirana: Academy of Sciences of Albania.

Topalli, K. (2016). Ndre Mjeda as a linguist. Pristina: Academy of Sciences and Art of Kosovo.

Ushaku, R. (2000). On onomastic motifs in the poem "Scodra" by Ndre Mjeda. Philology 8, Pristina: University of Pristina.

\section{AUTHORS BIODATA}

Shyhrete Morina is a teaching assistant at University of Gjakova "Fehmi Agani", Faculty of Education. She received her MA degree in Linguistics from University of Prishtina "Hasan Prishtina" and actually is a PhD candidate in Linguistics in South East European University. Her main focus of research is on phonetics, morhology, onomastics and ethnolinguistics. 